\title{
Duration of Type II DM, HbA1C Levels, TNF- $\alpha$ and IL-10 as Risk Factors for Level Charcot Joint Foot and Ankle in Type II DM Patients
}

\author{
Indra Rukmana Tri Pratistha ${ }^{1}$, Ketut Siki Kawiyana ${ }^{2}$, IGN Wien Aryana ${ }^{2}$ \\ ${ }^{1}$ Resident, Orthopedic and Traumatology Department, Faculty of Medicine Udayana University, RSUP. Sanglah \\ General Hospital, Bali. \\ ${ }^{2}$ Consultant, Orthopedic and Traumatology Department, Faculty of Medicine Udayana University, Sanglah \\ General Hospital, Denpasar, Bali. \\ Corresponding Author: Indra Rukmana Tri Pratistha
}

DOI: https://doi.org/10.52403/ijhsr.20220121

\begin{abstract}
Introduction: Type II Diabetes Mellitus has complications including disorders of the musculoskeletal system or what is often called diabetic charcot joint or charcot neuroarthropathy. Various risk factors are thought to increase the incidence of Charcot joint foot and ankle. Various studies have been made to assess these risk factors with the aim of reducing the occurrence of these complications.

Material and Methods: The study used an analytical observational design with a case study and control approach to determine whether Type II DM II $\geq 10$ years, HbA1c levels II $\geq 7 \%$, TNF- $\alpha$ levels II $\geq 1.0 \mathrm{ng} / \mathrm{L}$ and IL-10 levels $\leq 255 \mathrm{pg} / \mathrm{mL}$ as factors. risk of Charcot joint foot and ankle in Type II DM patients. Where the sample involves 24 case groups and 24 control groups. Then a descriptive analysis was performed, bivariate inferential analysis using the chi-square test and an assessment of the risk factor odds ratio (OR). Then multivariate analysis was performed to assess the strength of the influence of risk factors using logistic regression test

Results: There is a significant difference between Type II DM II $\geq 10$ years, HbAlc levels II $\geq 7 \%$, TNF- $\alpha$ levels II $\geq 1.0 \mathrm{ng} / \mathrm{L}$, and IL-10 levels $\leq 255 \mathrm{pg} / \mathrm{mL}$ which are risk factors for the occurrence of charcot joint foot and ankle in Type II DM patients. The duration of type II DM II $\geq 10$ years had the strongest relationship while IL-10 $\leq 255 \mathrm{pg} / \mathrm{mL}$ had the weakest relationship for the occurrence of Charcot joint foot and ankle in Type II DM patients.

Conclusion: Increased duration of Type II DM, HbA1c level and TNF- $\alpha$ level above certain level and low IL-10 amount are risk factor for Charcot joint foot and ankle in Type II DM patients, with the duration of type II DM being the strongest risk factor.
\end{abstract}

Keywords: Diabetes mellitus type II, charcot joint foot and ankle, risk factors

\section{INTRODUCTION}

Diabetes mellitus (DM) is a major health problem, with the people living with it are increasing over time. Data from global studies show that the number of people with diabetes mellitus in 2011 has reached 366 million people, and it is expected to increase to 552 million by $2030 .{ }^{1}$ If not properly treated, DM can cause various complications affecting numerous organs such as the heart, eyes, kidneys, blood vessels, nerves and even the musculoskeletal system. Charcot Neuroarthopathy (CNA) is a complication of diabetic neuropathy, which is characterized an inflammatory process that can lead to damages in the bones and joints, affecting the shape and function of the foot. ${ }^{3}$

There are several risk factors for developing CNA in patients with DM, such 
as age, gender, duration of diabetes mellitus and levels of HbA1c. Several studies have shown that increased HbAlc levels play a significant role in peripheral neuropathy which is associated with occurrence of CNA. However, since CNA is a chronic inflammatory process, there are some factors contributing to it, such as pro inflammatory cytokines (IL-1). This inflammatory cascade has an effect in increasing bone resorption by elevating osteoclast activity which can lead to CNA in people with DM. Therefore, it is important to know the risk factors for the occurrence of CNA in diabetes mellitus patients so that prevention can be done earlier in order to reduce the incidence of CNA in patients with DM. ${ }^{4,5}$

This research aims to know the relationship between the incidence of Charcot Neuroarthropathy and the duration of Type II DM, HbA1c levels, TNF- $\alpha$ levels and IL-10 levels in Type II DM patients.

\section{MATERIAL AND METHODS}

This research is an analytic observational study with a case control study to analyze if Type II diabetes is $\geq 10$ years, HbAlc levels $\geq 7 \%$, TNF- $\alpha$ levels $\geq$ $1.0 \mathrm{ng} / 1$ and IL-10 levels $\leq 255 \mathrm{pg} / \mathrm{ml}$ as a risk factor for charcot joint foot and ankle in Type II DM patients. This research was conducted Sanglah General Hospital Denpasar, from February 2021 until August 2021. The research protocol for Ethical Clearance from the Research Ethics Commission at the Faculty of Medicine, UNUD / Sanglah Hospital Denpasar was submitted before the research was carried out. Subjects were given an explanation of the purpose of the study and were asked to fill out written informed consent

The incidence of foot and ankle charcot joints was done clinically and the investigations were assessed with plain radiographs. The case group is comprised of type II DM patients suffering from charcot joint foot and ankle diagnosed based on clinical pictures and plain radiographs. The type II DM patients without charcot joint of foot and ankle who did not suffer from charcot joint belong to the control group. Patients' data and medical conditions (name, age, gender, occupation, residence, smoking habits, use of corticosteroids, long history of diabetes mellitus type II, other diseases such as hyperlipidemia, hypertension, foot and ankle fracture, and peripheral artery disease) were obtained through anamnesis in the Outpatient Installation and Inpatient Installation of RSUP Sanglah and medical record. Diagnosis of charcot joint foot and ankle was obtained from the results of physical examination of according to Eichenholtz Classification and $\mathrm{x}$-ray examination of foot and ankle which was performed at the Radiology Installation of RSUP Sanglah. The inferential analysis was used determine whether the results of this study can be generalized to the general population, using $95 \% \mathrm{CI}$ and p-value $<0.05$ was considered as significant. The inferential statistical test used in this study was chi-square. Logistic regression was used to assess several major risk factors with the strongest influence on the incidence of Charcot joint foot and ankle in type II Diabetes Mellitus. Statistical Package for Social Sciences (SPSS) for Windows ${ }^{\circledR}$ version 20 program was used for data processing.

The sample size in this study was determined by consecutive sampling, namely by recording patients according to the inclusion and exclusion criteria until the number of participants according to the requirements of the analysis was met. A comparative case study and analytical control formula was used to calculate the sample size. The inclusion criteria are Patients who are diagnosed with type II DM with charcot joint foot and ankle and patients who are willing to participate in the study with informed consent form. The exclusion criteria are patient with routine use of corticosteroid, no habit and previous history of smoking, patients who refuse to participate in the study, patients with neuritis / neuropathy of the lower extremity due to other causes other than type II DM, 
and patients with history of ankle reconstruction surgery.

\section{RESULTS}

The descriptive analysis was done to see the distribution of the characteristics of the research subjects (Table 1). Based on the demographic data gathered, male gender dominated both the Type II DM group with Charcot joint foot and ankle and the Type II DM group without Charcot joint foot and ankle, which were $51.9 \%$ and $48.1 \%$ respectively. From the side of the foot affected, most of the subjects in the Type II DM group with Charcot joint foot and ankle were on the right foot side with 15 people (62.5\%). Based on the Eichenholtz classification in the Type II DM group with Charcot joint foot and ankle, the highest number was found at stadium III with 17 people $(70.8 \%)$ and the lowest at stadium II with 2 people $(8.3 \%)$. The most common duration of Type II DM in the Type II DM group with Charcot joint foot and ankle was $\geq 10$ years with 14 people $(58.3 \%)$, while in the Type II DM group without Charcot joint foot and ankle, the number of subjects with of duration of type II DM $<10$ years was 20 people $(83.3 \%)$ with a standard deviation of both groups $8.42 \pm 5.77$. The results of the HbA1c examination in both groups showed HbA1c levels of $7 \%$ found in 16 people $(66.7 \%)$ in the case group, while in the control group the HbA1c levels were $<7 \%$ found in 15 people $(62.5 \%)$ with a deviation standard $7.88 \pm 3.02$. The results of the TNF- $\alpha$ examination in the two groups showed the TNF- $\alpha$ levels $1.0 \mathrm{ng} / \mathrm{L}$ is the most common result in the case group with 19 people (79.2\%), while TNF- $\alpha$ levels $<1.0$ $\mathrm{ng} / \mathrm{L}$ in 14 people. (58.3\%) in the control group with a standard deviation of $14.67 \pm$ 14.67. The results of the IL-10 examination showed IL-10 levels $255 \mathrm{pg} / \mathrm{mL}$ were found in 20 people $(83.3 \%)$ in the case group. While in the control group, the most common result was IL-10 levels > 255 $\mathrm{pg} / \mathrm{mL}$ with 13 people (54.2\%) with a standard deviation of $177.34 \pm 170,34$ for both groups.

Table 1. The Distribution of Characteristics of the Research Subjects

\begin{tabular}{|c|c|c|c|}
\hline \multirow[t]{2}{*}{ Variable } & \multicolumn{2}{|l|}{ Total $(\%)$} & \multirow[t]{2}{*}{ Mean \pm Standard Deviation } \\
\hline & $\begin{array}{l}\text { Type II DM with Charcot joint foot } \\
\text { and ankle }\end{array}$ & $\begin{array}{l}\text { Type II DM without Charcot joint } \\
\text { foot and ankle }\end{array}$ & \\
\hline Age (years) & & & $54.25 \pm 10.373$ \\
\hline $\begin{array}{l}\text { Sex } \\
\text { Male } \\
\text { Female }\end{array}$ & $\begin{array}{l}14(58.3 \%) \\
10(41.7 \%) \\
\end{array}$ & $\begin{array}{l}13(54.2 \%) \\
11(45.8 \%)\end{array}$ & \\
\hline $\begin{array}{l}\text { The affected side } \\
\text { Right } \\
\text { Left }\end{array}$ & $\begin{array}{l}15(62.5 \%) \\
9(37.5 \%)\end{array}$ & $\begin{array}{l}0(0 \%) \\
0(0 \%)\end{array}$ & \\
\hline $\begin{array}{l}\text { Eichenholtz stadium } \\
\text { Stadium II } \\
\text { Stadium III } \\
\text { Stadium IV } \\
\end{array}$ & $\begin{array}{l}2(8.3 \%) \\
17(70.8 \%) \\
5(20.8 \%) \\
\end{array}$ & $\begin{array}{l}0(0 \%) \\
0(0 \%) \\
0(0 \%) \\
\end{array}$ & \\
\hline $\begin{array}{l}\text { Duration of Type II } \\
\text { DM } \\
<10 \text { years } \\
\geq 10 \text { years }\end{array}$ & $\begin{array}{l}10(41.7 \%) \\
14(58.3 \%) \\
\end{array}$ & $\begin{array}{l}20(83.3 \%) \\
4(16.7 \%)\end{array}$ & $8.42 \pm 5.77$ \\
\hline $\begin{array}{l}\text { HbA1c Level } \\
\text { HbA1c } \geq 7 \% \\
\text { HbA1c }<7 \% \\
\end{array}$ & $\begin{array}{l}16(66.7 \%) \\
8(33.3 \%)\end{array}$ & $\begin{array}{l}9(37.5 \%) \\
15(62.5 \%)\end{array}$ & $7.88 \pm 3.02$ \\
\hline $\begin{array}{l}\text { TNF- } \alpha \text { Level } \\
\text { TNF- } \alpha \geq 1,0 \mathrm{ng} / \mathrm{L} \\
\text { TNF- } \alpha<1,0 \mathrm{ng} / \mathrm{L}\end{array}$ & $\begin{array}{l}19(79.2 \%) \\
5(20.8 \%)\end{array}$ & $\begin{array}{l}10(41.7 \%) \\
14(58.3 \%)\end{array}$ & $14.67 \pm 14.67$ \\
\hline $\begin{array}{l}\text { IL-10 Level } \\
\text { IL-10 } \leq 255 \mathrm{pg} / \mathrm{mL} \\
\mathrm{IL}-10>255 \mathrm{pg} / \mathrm{mL}\end{array}$ & $\begin{array}{l}20(83.3 \%) \\
4(16.7 \%)\end{array}$ & $\begin{array}{l}11(45.8 \%) \\
13(54.2 \%)\end{array}$ & $177.34 \pm 170.34$ \\
\hline
\end{tabular}

The duration of Type II DM $\geq 10$ years and Charcot joint foot and ankle in patients with Type II DM can be seen on Table 2. There is a significant difference $(\mathrm{p}=$ $0.003, \mathrm{p}<0.05$ ) between the duration of
Type II DM $\geq 10$ years and $<10$ years. Further analysis obtained an Odd Ratio (OR) of 7 so that patients with Type II DM $\geq 10$ years had a 7 times higher risk of developing Charcot joint foot and ankle 
compared to the population with Type II $\mathrm{DM}<10$ years. Based on the p-value $=$ 0.003 and $\mathrm{CI} 95 \%=1.822-26,887$, this odd ratio value can be generalized to the general population.

Table 2. The duration of Type II DM $\geq 10$ years and Charcot joint foot and ankle in patients with Type II DM

\begin{tabular}{|l|l|l|l|l|}
\hline Variable & Type II DM groups & P & \multicolumn{1}{|c|}{ OR (95\% CI) } \\
\hline & With Charcot joint foot and ankle & Without Charcot joint foot and ankle & & \\
\hline $\begin{array}{l}\text { Duration of Type II DM } \\
<10 \text { years }\end{array}$ & $\begin{array}{l}20(83,3 \%) \\
4(16.7 \%)\end{array}$ & \multirow{2}{*}{0.003} \\
$\geq 10$ years & $10(41.7 \%)$ & $7.822-26.887)$ \\
\hline
\end{tabular}

The HbA1c level and Charcot joint foot and ankle in patients with Type II DM can be seen in Table 3. There was a statistically significant difference in risk of Charcot joint foot and ankle ( $\mathrm{p}=0.043, \mathrm{p}<$ 0.05 ) between Type II DM patients with $\mathrm{HbAlc} \geq 7 \%$ compared to HbAlc $<7 \%$. Further analysis obtained an Odd Ratio (OR) of 3.333 so that patients with higher
HbAlc levels (HbAlc levels $\geq 7 \%$ ) had a 3.333-fold greater probability of Charcot joint foot and ankle compared to the population with lower HbAlc levels (HbA1c levels $<7 \%)$. The p-value $=0.043$ and $95 \% \mathrm{CI}=(1.020-10.898)$ means that the odds ratio value obtained can be generalized to the general population.

Table 3. The HbA1c level and Charcot joint foot and ankle in patients with Type II DM

\begin{tabular}{|l|l|l|l|l|}
\hline Variable & \multicolumn{2}{|l|}{ Type II DM groups } & P & OR (95\% CI) \\
\hline & With Charcot joint foot and ankle & Without Charcot joint foot and ankle & & \\
\hline $\begin{array}{l}\text { HbA1c Level } \\
\geq 7 \%\end{array}$ & $16(66.7 \%)$ & $9(37.5 \%)$ & & \\
$<7 \%$ & $8(33.3 \%)$ & $15(62.5 \%)$ & 0.043 & 3.333 \\
$(1.020-10.898)$ \\
\hline
\end{tabular}

TNF- $\alpha$ levels and Charcot joint foot and ankle in patients with Type II DM can be seen in Table 4 . There was a statistically significant difference $(p=0.008, p<0.05)$ between TNF- $\alpha$ levels $\geq 1.0 \mathrm{ng} / \mathrm{L}$ compared to TNF- $\alpha$ levels $<1.0 \mathrm{ng} / \mathrm{L}$. Further analysis obtained an Odd Ratio (OR) of 5.320 so that the type II DM patients with TNF- $\alpha$ levels $\geq 1.0 \mathrm{ng} / \mathrm{L}$ had 5.320 times the higher probability for Charcot joint foot and ankle compared to the population with TNF- $\alpha$ $<1.0 \mathrm{ng} / \mathrm{L}$. With $95 \% \mathrm{CI}=(1.485-19.064)$ and $\mathrm{p}$-value $=0.008$, this odd ratio value can be generalized to the general population.

Table 4. TNF- $\alpha$ levels and Charcot joint foot and ankle in patients with Type II DM

\begin{tabular}{|l|l|l|l|l|}
\hline Tariable & Type II DM groups & P & OR (95\% CI) \\
\hline & With Charcot joint foot and ankle & Without Charcot joint foot and ankle & & \\
\hline TNF- $\alpha$ Level & & $10(41.7 \%)$ & & \\
$\geq 1.0 \mathrm{ng} / \mathrm{L}$ & $19(79.2 \%)$ & $14(58.3 \%)$ & 0.008 & 5.320 \\
$<1.0 \mathrm{ng} / \mathrm{L}$ & $5(20.8 \%)$ & $(1.485-19.064)$ \\
\hline
\end{tabular}

Level of IL-10 and Charcot joint foot and ankle in patients with Type II DM can be seen in Table 5. There was a statistically significant difference $(\mathrm{p}=0.007$, $\mathrm{p}<0.05$ ) between IL-10 levels $\leq 255 \mathrm{pg} / \mathrm{mL}$ compared to IL-10 levels $>255 \mathrm{pg} / \mathrm{mL}$. Further analysis obtained an Odd Ratio (OR) of 5.909 so that type II DM patients with IL-10 levels $\leq 255 \mathrm{pg} / \mathrm{mL}$ had a 5.909fold higher possibility of Charcot joint foot and ankle compared to the population with IL-10 $\leq 255 \mathrm{pg} / \mathrm{mL}$. With $95 \% \mathrm{CI}=1.546-$ 22.580 and $p$-value $=0.007$, the odds ratio value can be generalized to the general population.

Table 5. Level of IL-10 and Charcot joint foot and ankle in patients with Type II DM

\begin{tabular}{|l|l|l|l|l|}
\hline Variable & Type II DM groups & P & OR (95\% CI) \\
\hline & With Charcot joint foot and ankle & Without Charcot joint foot and ankle & & \\
\hline IL-10 Levels & & $11(45.8 \%)$ & & \\
$\leq 255 \mathrm{pg} / \mathrm{mL}$ & $20(83.3 \%)$ & $13(54.2 \%)$ & 0.007 & 5.909 \\
$>255 \mathrm{pg} / \mathrm{mL}$ & $4(16.7 \%)$ & $(1.546-22.580)$ \\
\hline
\end{tabular}


Based on the multivariate analysis, it can be seen in Table 6 that the strongest risk factors of Charcot joint foot and ankle was the duration of Type II $\mathrm{DM} \geq 10$ years $(\mathrm{RR}=9,767)$, while the weakest risk factor was IL-10 levels $\leq 255 \mathrm{pg} / \mathrm{mL}(\mathrm{RR}-0,149)$.

Table 6. Risk factors of Charcot joint foot and ankle in type II DM patients

\begin{tabular}{|c|c|c|c|}
\hline \multirow{2}{*}{ Risk Factors } & \multirow[t]{2}{*}{$\operatorname{Exp}(B)$} & \multicolumn{2}{|c|}{$95 \%$ CI for $\operatorname{Exp}(B)$} \\
\hline & & Lower & Upper \\
\hline $\begin{array}{l}\text { Duration of Type II } \\
\text { DM tipe } \geq 10 \text { tahun }\end{array}$ & 9.767 & 1.657 & 57.557 \\
\hline $\mathrm{HbA} 1 \mathrm{c} \geq 7 \%$ & 2.842 & 0.607 & 13.310 \\
\hline TNF- $\alpha \geq 1,0 \mathrm{ng} / \mathrm{L}$ & 3.751 & 0.812 & 17.337 \\
\hline $\mathrm{IL}-10 \leq 255 \mathrm{pg} / \mathrm{mL}$ & 0.149 & 0.24 & 0.904 \\
\hline
\end{tabular}

\section{DISCUSSION}

This study showed that there are multiple risk factors in the development of Charcot joint foot and ankle, which are the duration of type II DM $\geq 10$ years, $\mathrm{HbA} 1 \mathrm{c} \geq$ $7 \%$, TNF- $\geq 1.0 \mathrm{ng} / \mathrm{L}$, and $\mathrm{IL}-10 \leq 255$ $\mathrm{pg} / \mathrm{mL}$. A previous cross-sectional study by Wanzou et al. ${ }^{8}$ evaluated the factors associated with the incidence of Charcot joint foot and ankle in patients with type II DM at a referral hospital in Uganda. It was found that $43 \%$ of all patients had a duration of type II diabetes $>10$ years. Meanwhile, in another case-control study by Fauzi et al. ${ }^{9}$ in Malaysia, it was observed that from 48 cases of type II DM patients with Charcot joint, it showed that duration of type II DM had a significant relationship to the occurrence of Charcot joint, with the majority of patients $(89.4 \%)$ had duration of type II $\mathrm{DM} \geq 10$ years. It was concluded that duration of type II $\mathrm{DM} \geq 10$ years increases the risk of Charcot joint foot and ankle up to 6.7 times compared to the group with a duration of type II DM $<10$ years. In another study conducted by Stuck et al. ${ }^{5}$, it was also found that patients with type II DM duration > 6 years had Charcot joint foot and ankle at a rate twice as high as those with type II DM 6 years.

In this study, it was shown that HbAlc $\geq 7 \%$ was significantly associated with the incidence of Charcot joint foot and ankle. This result is similar to a study by Younis et al. ${ }^{9}$, which stated that there was a significant relationship between the occurrence of the Charcot joint with HbA1c levels $\geq 6.6 \%$ with an increase in the risk of almost 4.3 times higher compared to the HbA1c level of $<6.6 \%$. However, another study by Dardari et al. ${ }^{70}$ concluded that aggressively lowered $\mathrm{HbA1c}$ levels in patients with a history of uncontrolled diabetes significantly increased the onset of Charcot joint foot and ankle. This aggressive reduce in HbAlc levels in uncontrolled diabetic patients will cause activation of inflammatory phenomena through the OPG pathway, which triggers the development of Charcot joint foot and ankle.

It was also found that TNF- $\alpha$ levels $\geq 1.0 \mathrm{ng} / \mathrm{L}$ plays a significant role in the development of Charcot joint foot and ankle. TNF- $\alpha$ is a pro-inflammatory cytokine that has an important role in the expression of the RANKL gene, causing a local process of osteolysis and disrupting the integrity of bone tissue so that patients with diabetes have a high risk of fracture, deformity, and ulceration. $^{68}$ A study conducted by Petrova et al.31 reported that TNF- $\alpha$ in the group of controlled diabetes patients without the Charcot joint were significantly higher than those with Charcot joint. Meanwhile, the TNF- $\alpha$ levels in the DM patients with Charcot joint were 1.3 ng/l higher during the fourth month followup compared to the controlled diabetes group and the healthy patient group. But there was a different result in a study conducted by Folestad et al. ${ }^{23}$ which stated that TNF- $\alpha$ levels increase when compared between controls of DM patients with healthy people. TNF- $\alpha$ levels are below or equal to the comparison of DM with CNA with healthy people, while the ratio of IL1RA / IL-1 $\beta$ is continuously higher in CNA patients. IL-6, TNF- $\alpha$, and IL-1RA started to increase one week after offloading to peak after 4 months before slowly decreasing.

IL $10<255 \mathrm{pg} / \mathrm{mL}$ is also found to be a risk factor for Charcot joint foot and ankle. IL-10 acts as an important immunoregulator, by reducing the 
production of proinflammatory cytokines and reactive oxygen species that cause cell damage. IL-10 is known to be produced by $\mathrm{T}$ helper 2 cells, B cells, mast cells, and granulocytes. ${ }^{35}$ Until now, there are still few studies that explain the relationship between IL-10 level and type II DM and Charcot joint foot and ankle, thus, further investigations are needed to know about the balance between anti-inflammatory and proinflammatory cytokines since high inflammation is not affected by the IL-10 levels. Bio molecularly, low levels of IL-10 will increase proinflammatory cytokines such as TNF- $\alpha$, IL-1 $\beta$, and IL-6 which results in high local inflammation, maturation, and proliferation of osteoclasts through the RANKL pathway, which can lead to Charcot joint foot and ankle. ${ }^{21,69} \mathrm{~A}$ descriptive study conducted by JohnsonLynn et al. ${ }^{21}$ from 66 articles stated that in CNA severe chronic inflammation occurs, thereby increasing the production of proinflammatory cytokines such as TNF- $\alpha$, IL1 $\beta$, and IL6. At the same time, even at lower levels, there was increased expression of anti-inflammatory cytokines such as IL-4 and IL-10. ${ }^{70}$

\section{CONCLUSION}

In conclusion, there were multiple significant risk factors in the development of Charcot joint foot and ankle in patients with type $2 \mathrm{DM}$. It was found that duration of type II DM $\geq 10$ years was the strongest risk factors compared to other risk factors evaluated in this study. The low level of IL10 was found to be the weakest risk factor, as concluded in other studies assessing IL10 level in Charcot joint foot and ankle patients with type $2 \mathrm{DM}$.

\section{ACKNOWLEDGEMENTS}

We would like to thank Ketut Gede Mulyadi Ridia as Head of Orthopaedics and Traumatology Department, Faculty of Medicine Udayana University, Sanglah General Hospital for all the support regarding this study.
Funding: The author is responsible for funding this study without involving sponsors, grants, and various other funding sources.

Conflict of Interest: The author states that there is no conflict of interest related to the material discussed in the manuscript.

Ethical Approval: The research protocol for Ethical Clearance from the Research Ethics Commission at the Faculty of Medicine, UNUD / Sanglah Hospital Denpasar will be submitted before the research is carried out. Subjects who met the study criteria were given an explanation of the purpose of the study and were asked to fill out written informed consent. Researchers have also attached a secondary data collection permit in the form of a medical record at Sanglah Hospital Denpasar

Authors' Contribution: Indra Rukmana Tri Pratistha is responsible for finding research samples, implementing actions, and analyzing data, and reporting on research results. Ketut Siki Kawiyana, IGN Wien Aryana, I Gede Eka Wiratnaya, and KG Mulyadi Ridia were responsible for the research design concept and the supervisor in this study.

\section{REFERENCES}

1. WHO (2016) 'Diabetes Country Profiles', World Health Organization.

2. Mirzaei, Masoud et al. (2020) 'Epidemiology of diabetes mellitus, prediabetes, undiagnosed and uncontrolled diabetes in Central Iran: Results from Yazd health study', BMC Public Health. doi: 10.1186/s12889-020-8267-y.

3. Yagihashi, S., Mizukami, H. and Sugimoto, K. (2011) 'Mechanism of diabetic neuropathy: Where are we now and where to go?', Journal of Diabetes Investigation. doi: 10.1111/j.2040-1124.2010.00070.x.

4. Kucera, T., Shaikh, H. H. and Sponer, P. (2016) 'Charcot Neuropathic Arthropathy of the Foot: A Literature Review and SingleCenter Experience', Journal of Diabetes Research. doi: 10.1155/2016/3207043. 
5. Stuck, R. M. et al. (2008) 'Charcot Arthropathy Risk Elevation in the Obese Diabetic Population', American Journal of Medicine. doi: 10.1016/j.amjmed.2008.06.038.

6. Leung, H. B., Ho, Y. C. and Wong, W. C. (2009) 'Charcot foot in a Hong Kong Chinese diabetic population', Hong Kong Medical Journal.

7. Nóbrega, M. B. D. M. et al. (2015) 'Risk factors for charcot foot', Archives of Endocrinology and Metabolism. doi: 10.1590/2359-3997000000042.

8. Wanzou, J. P. V. et al. (2019) 'Charcot arthropathy of the diabetic foot in a subSaharan tertiary hospital: A cross-sectional study', Journal of Foot and Ankle Research. doi: 10.1186/s13047-019-0343-0.

9. Fauzi, A. A., Chung, T. Y. and Latif, L. A. (2016) 'Risk factors of diabetic foot Charcot arthropathy: A case-control study at a Malaysian tertiary care centre', Singapore Medical Journal. doi: 10.11622/smedj.2016074.

10. Frykberg, R. G. and Belczyk, R. (2008) 'Epidemiology of the Charcot Foot', Clinics in Podiatric Medicine and Surgery. doi: 10.1016/j.cpm.2007.10.001.

11. Rathmann, W., Bongaerts, B. and Kostev, K. (2018) 'Association of characteristics of people with type 2 diabetes mellitus with discordant values of fasting glucose and HbA1c', Journal of Diabetes. doi: 10.1111/1753-0407.12823.

12. Salvotelli, L. et al. (2015) 'Prevalence of neuropathy in type 2 diabetic patients and its association with other diabetes complications: The Verona Diabetic Foot Screening Program', Journal of Diabetes and its Complications. doi: 10.1016/j.jdiacomp.2015.06.014

13. Coppini, D. V. et al. (2001) 'The natural history of diabetic peripheral neuropathy determined by a 12 year prospective study using vibration perception thresholds', Journal of Clinical Neuroscience. doi: 10.1054/jocn.2001.0893.

14. Coppini, D. V. et al. (2006) 'Established diabetic neuropathy seems irreversible despite improvements in metabolic and vascular risk markers - A retrospective casecontrol study in a hospital patient cohort', Diabetic Medicine. doi: 10.1111/j.14645491.2006.01934.x.
15. Li, L. et al. (2015) 'Prevalence and risk factors of diabetic peripheral neuropathy in Type 2 diabetes mellitus patients with overweight/obese in Guangdong province, China', Primary Care Diabetes. doi: 10.1016/j.pcd.2014.07.006.

16. Mehlhorn, A. T. et al. (2016) 'Complication assessment and prevention strategies using midfoot fusion bolt for medial column stabilization in Charcot's osteoarthropathy', Foot. doi: 10.1016/j.foot.2016.10.005.

17. Apley and Solomon (2018) SYSTEM OF ORTHOPAEDICS AND TRAUMA, Taylor $\&$ Francis Group.

18. Armstrong, D. G. et al. (1997) 'Infrared dermal thermometry for the high-risk diabetic foot', Physical Therapy. doi: 10.1093/ptj/77.2.169.

19. Petrova, Nina L. et al. (2015) 'Inhibition of tnf- $\alpha$ reverses the pathological resorption pit profile of osteoclasts from patients with acute charcot osteoarthropathy', Journal of Diabetes Research. doi: 10.1155/2015/917945.

20. Parameswaran, N. and Patial, S. (2010) 'Tumor necrosis factor-a signaling in macrophages', Critical Reviews in Eukaryotic Gene Expression. doi: 10.1615/CritRevEukarGeneExpr.v20.i2.10.

21. Johnson-Lynn, S. E. et al. (2018) 'Neuroarthropathy in diabetes: Pathogenesis of charcot arthropathy', Bone and Joint Research. doi: 10.1302/2046-3758.75.BJR2017-0334.R1.

22. Mascarenhas, J. V. and Jude, E. B. (2013) 'Pathogenesis and medical management of diabetic Charcot neuroarthropathy', Medical Clinics of North America. doi: 10.1016/j.mcna.2013.05.002.

23. Folestad, A. et al. (2015) 'Offloading treatment is linked to activation of proinflammatory cytokines and start of bone repair and remodeling in Charcot arthropathy patients', Journal of Foot and Ankle Research. doi: 10.1186/s13047-0150129-y.

24. 'Stedman's medical dictionary for the health professions and nursing' (2005) Choice Reviews Online. doi: 10.5860/choice.425613.

25. Ozougwu, O. (2013) 'The pathogenesis and pathophysiology of type 1 and type 2 diabetes mellitus', Journal of Physiology and Pathophysiology. doi: 10.5897/jpap2013.0001. 
26. Jameson JL; Fausi AS et al. (2018) Harrison's Principles of Internal Medicine, 20e, McGraw-Hill.

27. Soelistijo, S. A. et al. (2019) 'Pedoman pengelolaan dan pencegahan diabetes melitus tipe 2 dewasa di Indonesia 2019', Perkumpulan Endokrinologi Indonesia.

28. Ziegler, D., Papanas, N. and Roden, M. (2011) 'Neuropad: Evaluation of three cutoff points of sudomotor dysfunction for early detection of polyneuropathy in recently diagnosed diabetes', Diabetic Medicine, 28(11), pp. 1412-1415. doi: 10.1111/j.1464-5491.2011.03345.x.

29. Birsel, O. et al. (2013) 'Etiology, pathophysiology and classifications of the diabetic Charcot foot', Diabetic Foot and Ankle, 4(4), pp. 1-5. doi: 10.3402/dfa.v4i0.20872.

30. Yousaf S, Dawe EJC, Saleh A, et al. (2018) The acute Charcot foot in diabetics: Diagnosis and management. EFORT Open Reviews 3(10): 568-573. DOI: 10.1302/2058-5241.3.180003.

31. Petrova, N. L. et al. (2015) 'Inflammatory and bone turnover markers in a crosssectional and prospective study of acute Charcot osteoarthropathy', Diabetic Medicine. doi: 10.1111/dme.12590.

32. Ergen FB, Sanverdi SE and Oznur A (2013) Charcot foot in diabetes and an update on imaging. Diabetic Foot and Ankle 4(February). DOI: 10.3402/dfa.v4i0.21884.

33. Palestro CJ, Kipper SL, Weiland FL, et al. (2002) Osteomyelitis: Diagnosis with 99mTc-labeled Antigranulocyte Antibodies Compared with Diagnosis with 111Inlabeled Leukocytes-Initial Experience1. https://doi.org/10.1148/radiol.2233011072 223(3). Radiological Society of North America: 758-764. DOI: 10.1148/RADIOL.2233011072.

34. Basu S, Chryssikos T, Houseni M, et al. (2007) Potential role of FDG PET in the setting of diabetic neuro-osteoarthropathy: can it differentiate uncomplicated Charcot's neuroarthropathy from osteomyelitis and soft-tissue infection? Nuclear Medicine Communications 28(6): 465-472. DOI: 10.1097/MNM.0b013e328174447f.

35. Iyer, S. S. and Cheng, G. (2012) 'Role of interleukin 10 transcriptional regulation in inflammation and autoimmune disease', Critical Reviews in Immunology. doi: 10.1615/critrevimmunol.v32.i1.30.
36. Ertugrul BM, Lipsky BA and Savk O (2013) Osteomyelitis or charcot neuroosteoarthropathy? differentiating these disorders in diabetic patients with a foot problem. Diabetic Foot and Ankle 4(February). DOI: 10.3402/dfa.v4i0.21855Milne, T. E. et al. (2013) 'Developing an evidence-based clinical pathway for the assessment, diagnosis and management of acute Charcot Neuro-Arthropathy: A systematic review', Journal of Foot and Ankle Research. doi: 10.1186/1757-1146-6-30.

37. Rogers, L. C. et al. (2011) 'The Charcot foot in diabetes', Diabetes Care. doi: 10.2337/dc11-0844.

38. Younis, B. Bin et al. (2015) 'Charcot osteoarthropathy in type 2 diabetes persons presenting to specialist diabetes clinic at a tertiary care hospital', pp. 1-5. doi: 10.1186/s12902-015-0023-4.

39. Rastogi, A., Prakash, M. and Bhansali, A. (2019) 'Varied presentations and outcomes of Charcot neuroarthropathy in patients with diabetes mellitus', International Journal of Diabetes in Developing Countries. doi: 10.1007/s13410-018-0700-8.

40. Roodman, G. D. et al. (1992) 'Interleukin 6: A potential autocrine/paracrine factor in Paget's disease of bone', Journal of Clinical Investigation. doi: 10.1172/JCI115584.

41. Gough, A. et al. (1997) 'Measurement of markers of osteoclast and osteoblast activity in patients with acute and chronic diabetic charcot neuroarthropathy', Diabetic Medicine. doi: 10.1002/(SICI)10969136(199707) $14: 7<527:: A I D-$ DIA404>3.0.CO;2-Q.

42. Lam, J. et al. (2002) 'Tumour necrosis factor superfamily cytokines and the pathogenesis of inflammatory osteolysis', in Annals of the Rheumatic Diseases. doi: 10.1136/ard.61.suppl_2.ii82.

43. Redlich, K. and Smolen, J. S. (2012) 'Inflammatory bone loss: Pathogenesis and therapeutic intervention', Nature Reviews Drug Discovery. doi: 10.1038/nrd3669.

44. Molligan, J. et al. (2016) 'Pathological role of fibroblast-like synoviocytes in charcot neuroarthropathy', Journal of Orthopaedic Research. doi: 10.1002/jor.22989.

45. Mabilleau, G. et al. (2011) 'Number of circulating CD 14-positive cells and the serum levels of TNF- $\alpha$ are raised in acute 
charcot foot', Diabetes Care. doi: $10.2337 / \mathrm{dc} 10-1695$.

46. Steen, E. H. et al. (2020) 'The Role of the Anti-Inflammatory Cytokine Interleukin-10 in Tissue Fibrosis', Advances in Wound Care. doi: 10.1089/wound.2019.1032.

47. Kaynak, G. et al. (2013a) 'An overview of the Charcot foot pathophysiology', Diabetic Foot and Ankle. doi: 10.3402/dfa.v4i0.21117.

48. Ganda, I. J. et al. (2018) 'Initial serum level of IL-10 as an outcome predictor in children with sepsis', Current Pediatric Research.

49. Bowering, C. K. (2001) 'Diabetic foot ulcers: Pathophysiology, assessment, and therapy', Canadian Family Physician.

50. Clayton, W. and Elasy, T. A. (2009) 'A review of the pathophysiology, classification, and treatment of foot ulcers in diabetic patients', Clinical Diabetes. doi: 10.2337/diaclin.27.2.52.

51. Gibbons, C. H. and Freeman, R. (2015) 'Treatment-induced neuropathy of diabetes: An acute, iatrogenic complication of diabetes', Brain, 138(1), pp. 43-52. doi: 10.1093/brain/awu307.

52. Rayman, G. et al. (1986) 'Impaired microvascular hyperaemic response to minor skin trauma in type I diabetes', British Medical Journal (Clinical research ed.). doi: 10.1136/bmj.292.6531.1295.

53. Caballero, A. E. et al. (1999) 'Microvascular and macrovascular reactivity is reduced in subjects at risk for type 2 diabetes', Diabetes. doi: 10.2337/diabetes.48.9.1856.

54. Dinh, T. L. and Veves, A. (2005) 'A review of the mechanisms implicated in the pathogenesis of the diabetic foot', International Journal of Lower Extremity Wounds. doi: 10.1177/1534734605280130.

55. Sacks, D. B. (2012) 'Measurement of hemoglobin A1c: A new twist on the path to harmony', Diabetes Care. doi: $10.2337 / \mathrm{dc} 12-1348$.

56. Mirzaei, A. and Mahmoudi, H. (2018) 'Evaluation of TNF- $\alpha$ cytokine production in patients with tuberculosis compared to healthy people.', GMS hygiene and infection control. doi: 10.3205/dgkh000315.

57. Howes, A., Gabryšová, L. and O'Garra, A. (2014) 'Role of IL-10 and the IL-10 Receptor in Immune Responses', in Reference Module in Biomedical Sciences. doi: 10.1016/b978-0-12-801238-3.00014-3.
58. Harris, A. and Violand, M. (2018) Charcot Neuropathic Osteoarthropathy (Charcot Joint), StatPearls.

59. Ertugrul BM, Lipsky BA and Savk O (2013) Osteomyelitis or charcot neuroosteoarthropathy? differentiating these disorders in diabetic patients with a foot problem. Diabetic Foot and Ankle 4(February). DOI: 10.3402/dfa.v4i0.21855

60. Jacobson T, Maki K, Orringer $\mathrm{C}$, et al. (2015) National Lipid Association Recommendations for Patient-Centered Management of Dyslipidemia: Part 2. Journal of clinical lipidology 9(6 Suppl). J Clin Lipidol: S1-S122.e1. DOI: 10.1016/J.JACL.2015.09.002

61. Chobanian A V., Bakris GL, Black HR, et al. (2003) Seventh report of the Joint National Committee on Prevention, Detection, Evaluation, and Treatment of High Blood Pressure. Hypertension 42(6): 1206-1252.

DOI: 10.1161/01.HYP.0000107251.49515.c2.

62. Waljee AK, Rogers MAM, Lin P, et al. (2017) Short term use of oral corticosteroids and related harms among adults in the United States: population based cohort study. BMJ 357. British Medical Journal Publishing Group: j1415. DOI: 10.1136/BMJ.J1415.

63. Lawrence A, L. et al. (2019) 'Diabetic Foot Syndrome in the Twenty-First Century', Clinics in podiatric medicine and surgery, 36(3), pp. 355-359. doi: 10.1016/J.CPM.2019.02.002.

64. Rastogi, A. et al. (2020) 'Long term outcomes after incident diabetic foot ulcer: Multicenter large cohort prospective study (EDI-FOCUS investigators) epidemiology of diabetic foot complications study: Epidemiology of diabetic foot complications study', Diabetes Research and Clinical Practice, 162, p. 108113. doi: 10.1016/J.DIABRES.2020.108113.

65. Sämann, A. et al. (2012) 'Diabetic nephropathy but not $\mathrm{HbA} 1 \mathrm{c}$ is predictive for frequent complications of charcot feet Long-term follow-up of 164 consecutive patients with 195 acute charcot feet', Experimental and Clinical Endocrinology and Diabetes. doi: 10.1055/s-0031-1299705.

66. Id, D. D. et al. (2020) 'Rapid glycemic regulation in poorly controlled patients living with diabetes, a new associated factor in the pathophysiology of Charcot's acute 
Indra Rukmana Tri Pratistha et.al. Duration of type II DM, HbAIC levels, TNF- $\alpha$ and IL-10 as risk factors for level charcot joint foot and ankle in type II DM patients.

neuroarthropathy', pp. 1-6. doi 10.1371/journal.pone.0233168.

67. Zhao, H. M. et al. (2017) 'Pathogenesis and potential relative risk factors of diabetic neuropathic osteoarthropathy', Journal of Orthopaedic Surgery and Research, 12(1), pp. 1-8. doi: 10.1186/s13018-017-0634-8.

68. Kaynak, G. et al. (2013b) 'An overview of the Charcot foot pathophysiology', Diabetic Foot and Ankle, 4, pp. 1-10. doi: 10.3402/dfa.v4i0.21117.

69. Pitocco, D. et al. (2019) 'Charcot Neuroarthropathy: From the Laboratory to the Bedside', Current Diabetes Reviews, 16(1), pp. 62-72. doi: $10.2174 / 1573399815666190502121945$.
70. Dardari, D., et al. (2020). Rapid glycemic regulation in poorly controlled patients living with diabetes, a new associated factor in the pathophysiology of Charcot's acute neuroarthropathy. PloS One. https://doi.org/10.1371/JOURNAL.PONE.0 233168

How to cite this article: Indra Rukmana Tri Pratistha, Ketut Siki Kawiyana, IGN Wien Aryana. Duration of type II DM, HbA1C levels, TNF- $\alpha$ and IL-10 as risk factors for level charcot joint foot and ankle in type II DM patients. Int J Health Sci Res. 2022; 12(1):147156. DOI: https://doi.org/10.52403/ijhsr. 20220121 